\title{
FEATURES OF THE CRIMINAL IDENTITY IN ACTS OF EXTREMISM
}

\author{
Olga A. Yakovleva \\ Volgograd State University, Volgograd, Russian Federation
}

Introduction: the problem of studying the identity of a criminal has always been the focus of criminology, criminal law, criminal procedure, criminalistics and other legal sciences. The criminal identity has individual distinctive features and qualities. The aim of the work is to identify, analyze and evaluate the characteristics of individuals in extremist crimes, and fix them for further use in the law enforcement practice. Methods: the methodological framework for the research is a set of methods of scientific knowledge, among which, first of all, we should mention the methods of system analysis and synthesis. Results: the paper presents a criminological analysis of the criminal identity in acts of extremism. The classification of persons who commit crimes of this group of crimes is determined. The necessity of a comprehensive approach in the development of the state policy in the field of prevention of extremist crime is emphasized. Conclusions: persons who commit crimes of extremism can be divided into several categories: 1) gang delinquents and violent protesters; 2) individuals with religious ideas who are perpetrators of crimes of extremism; 3) persons who provide assistance (including organizational and sponsorship) to the extremist communities and groups, as well as attract extremist criminals for their power purposes.

Key words: extremism, criminal identity, crime committer, acts of extremism, crime.

Citation. Yakovleva O.A. Features of the Criminal Identity in Acts of Extremism. Legal Concept, 2020, vol. 19, no. 2, pp. 84-88. (in Russian). DOI: https://doi.org/10.15688/lc.jvolsu.2020.2.12

УДК 343.326

Дата поступления: 16.03.2020

ББК 67.408.141.8 Дата принятия: 05.04.2020

\section{ОСОБЕННОСТИ ЛИЧНОСТИ ПРЕСТУПНИКА В ДЕЯНИЯХ ЭКСТРЕМИСТСКОЙ НАПРАВЛЕННОСТИ}

\section{Ольга Алексеевна Яковлева}

Волгоградский государственный университет, г. Волгоград, Российская Федерация

\begin{abstract}
Введение: проблема изучения личности преступника всегда была предметом внимания криминологии, уголовного права, уголовного процесса, криминалистики и других юридических наук. Личность преступника имеет индивидуальные отличительные свойства и качества. В работе поставлена цель: выявление, анализ и правовая оценка свойств личности в преступлениях экстремистской направленности, их фиксация в целях дальнейшего использования в правоприменительной практике. Методы: методологической основой данного исследования послужил комплекс методов научного познания, среди которых в первую очередь следует назвать системный анализ, синтез. Результаты: в работе представлен криминологический анализ личности преступника в деяниях экстремистской направленности. Создана классификация лиц, совершающих преступления данной группы преступлений. Подчеркнута необходимость комплексного подхода в разработке государственной политики в области предотвращения экстремистской преступности. Выводы: лиц, совершающих преступления экстремистской направленности, условно можно разделить на несколько категорий: 1) молодые участники группировок и акций массовых протестов; 2) личности с религиозными идеями, являющиеся исполнителями преступлений экстремистской направленности; 3) лица, оказывающие содействие (в том числе организационное и спонсорское) экстремистским сообществам и группам, а также привлекающие преступников-экстремистов для своих властных целей.

Ключевые слова: экстремизм, личность преступника, субъект преступления, деяния экстремистской направленности, преступление.
\end{abstract}


Цитирование. Яковлева О. А. Особенности личности преступника в деяниях экстремистской направленности // Legal Concept = Правовая парадигма. -2020 . - Т. 19, № 2. - C. 84-88. - DOI: https://doi.org/10.15688/ lc.jvolsu.2020.2.12

\section{Введение}

Личность - это своеобразное «зеркало», позволяющее отразить все уникальные особенности человека и события, которые повлияли на формирование, развитие последнего и таким образом определили его поведение, в том числе преступное, отразив механизм данного поведения и ту роль, которую личность играет в самом преступлении. Иными словами, понятие личность можно представить как «социальное лицо человека» [3, с. 23].

По справедливому суждению ученых в области уголовного права и криминологии, огромную роль в профилактической работе с преступлениями играет изучение личности преступника, которое, по мнению В.Н. Кудрявцева, позволяет правоприменителю исследовать не только тех лиц, которые уже совершили преступление, но и тех, кто может совершить такие преступления в будущем. Данные выводы можно сделать, проанализировав правовой нигилизм потенциального преступника [5, с. 205].

Лишь проведя комплексный и всесторонний анализ структуры личности преступника, можно понять ее, учитывая все особенности и специфику [8, ст. 2]. Основными сведениями о личности преступника, которые необходимо рассматривать при профилактической индивидуальной работе с правонарушителями, являются: сведения об обстоятельствах, обусловивших преступное поведение, о преступном и ином противоправном поведении, о социально-демографических свойствах и ведущих отношениях личности, информация об индивидуально-психологических и иных особенностях личности, об условиях жизни, работы, а также ближайшем окружении.

\section{Сведения о личности как проявление следов ее индивидуальной специфики, информации социального и психического плана}

Личность - целостное явление, изучаемое философией, социальными науками из цикла юридических наук: криминологии, уголовного права, криминалистики.

Наука уголовного права и криминология содержат сведения о субъекте преступления, а также личности преступника. В свою очередь, криминалистика использует данные из уголовного права и криминологии. Кроме того, открытия и научные разработки в сфере криминалистики, а именно при создании портрета лица, совершившего преступное деяние, используются в смежных отраслях знания. Криминалистическая характеристика включает в себя сведения об индивидуальных чертах личности не только в механизме преступления, но и в процессах следообразования. Многие исследователи сходятся во мнении, что в предмет доказывания должна быть включена информация о личности. Так, согласно точке зрения Н.Н. Демидова, информация о личности преступника, которая отражает его социально-демографический статус, а также психофизиологические особенности данной личности, должны быть включены в пласт уголовно-процессуальных норм, регулирующих вопросы в сфере доказательств. Информация о социально-демографической стороне личности должна отражать следующие сведения: уровень образования, семейное и социальное положение, национальность, уровень жизни, место проживания, а также семейные отношения и отношения в трудовом коллективе. Психофизиологические особенности личности характеризуются следующими данными: характер личности, сфера мотивации, а также ее эмоциональное состояние и настрой [2, с. 21].

Указанные факторы детерминируются тем обстоятельством, что, совершая преступное деяние, личность взаимодействует с окружающим миром. Последнее, в свою очередь, непосредственным образом влияет на свойства личности, ее действия и поступки. Следствием этого является проявление следов, которые отражают информацию о личности, ее индивидуальную специфику, а также информацию социального и психического плана. 


\section{Характеристика личности преступника в преступлениях экстремистской направленности}

Успешное предупреждение преступлений экстремистской направленности возможно только в том случае, если внимание будет сконцентрировано на личности преступника, поскольку именно она является носителем причин их совершения, основным и важнейшим звеном всего механизма преступного поведения. При этом познание личности преступника экстремистской направленности предполагает непременный криминологический анализ свойств, качеств, признаков, охватываемых традиционной для любого криминологического исследования демонстрацией ее структуры.

В юридической науке вопрос о личности преступника-экстремиста является спорным. Отсутствует четкий ответ на вопрос о том, кто является экстремистом: лицо, совершающее конкретное преступление экстремистской направленности, указанное в уголовном законодательстве, либо лицо, которое совершило любое преступление по мотивам вражды или ненависти?

Часто сознание человека смешивает понятия «сторонник радикальных теорий» и «экстремист», то есть данное понятие получает широкую трактовку [6, с. 384]. Исходя из такой трактовки, экстремистом может быть признано любое лицо, которое нарушило волю граждан, установленную законодательно, и государственный политический режим. Как показал анализ научных источников, а также судебной практики, лицами, совершающими преступления экстремистской направленности, могут являться люди, имеющие разные криминологические характеристики. В первую очередь, речь идет о социально нестабильных личностях подросткового возраста без места работы или учебы.

В связи с этим В.А. Бурковская отмечает, что экстремизм в молодежной среде выражается в деформациях сознания, заинтересованности националистическими, неофашистскими идеологиями, нетрадиционными для РФ, в участии в деятельности радикальных движений и групп, в совершении противоправных, а иногда и преступных действий в соответствии со своими убеждениями [1, с. 154]. Указанные лица совершают подавляющее большинство преступлений на почве вражды или ненависти по различным мотивам (в частности, причинение вреда здоровью различной степени тяжести, акты вандализма, хулиганства и надругательств над местами захоронений), принимают активное участие в массовых беспорядках и погромах. Судя по данным, находящимся в открытом доступе, отсутствует единая техника подсчета участников неформальных молодежных объединений с насильственной экстремистской направленностью, правда, периодически та или иная организация объявляется экстремистской и ставится вне закона. Министерство юстиции ведет реестр, в который по решению суда вносят те организации, деятельность которых запрещена или приостановлена [4, с. 116]. Одним из факторов, вовлекающих рассматриваемую категорию лиц в действия экстремистской направленности, стал фактор пропаганды экстремизма в социальных сетях. Последние, образуя жизненную обстановку личности, изобилуют группами, в которых открыто пропагандируется религиозный экстремизм, размещаются материалы политико-экстремистской направленности. Информация может распространяться и как новостная рассылка от группы, в которой состоит пользователь, и от одного пользователя к другому, что определяет большую скорость ее распространения. А, так как молодой человек - пользователь сети воспринимает свою страничку как личное пространство, круг общения, который он определяет сам, то и доверие к получаемой информации у него выше, чем к информации, полученной из государственных средств массовой информации. Таким образом, антиобщественное поведение личности экстремистской направленности, членов криминогенных молодежных формирований характеризуется определенными особенностями. Одной из таких особенностей является то, что часто такое поведение - результат психических реакций на конкретные жизненные ситуации, в которых они пребывают, а не запрограммированное влияние индивидов с антиобщественными установками. На поведение личности оказывают огромное влияние те ее свойства, которые были индивидуально сформированы в результате воздействия внешней среды.

В другую категорию входят те лица, которые имеют образование и разный уровень 
достатка, совершают преступления из ненависти и вражды, проповедуют религиозный экстремизм. Мотив ненависти или вражды в действиях данных лиц установить достаточно сложно. В ходе экспертизы подобные деяния не признаются экстремистскими, или о них не становится известно вовремя правоохранительным органам. Так, из показаний гр. Т. следует, что он слушал длительное время в интернете религиозные проповеди, после чего бросил мединститут и решил стать участником группы экстремистской направленности. Его мать дала интервью, из которого было видно, что она не могла понять, как ее сын, всегда росший хорошим мальчиком, стал религиозным фанатом. Подобным образом вела себя студентка одного из высших учебных заведений, размещавшая в социальной сети видеоролики, которые содержали призыв ненавидеть врагов ислама и оправдывали экстремизм [4, с. 116].

Кроме идейных исполнителей преступлений экстремистского характера наибольшую общественную опасность представляют также организаторы таких преступлений, спонсоры преступных сообществ, политические деятели, которые, имея контакты с экстремистами, обеспечивают прикрытие преступникам в обмен на распространение идеологии экстремизма в обществе. В указанной группе преступников-экстремистов состоят в основном лица старшего возраста с материальным достатком и высшим образованием: учредитель экстремистской организации - юридическое лицо, фактическое поведение которого привело к появлению в деятельности религиозного или общественного объединения, либо иной организации признаков экстремизма. Coгласно законодательству, принимать участие в деятельности религиозной организации может лицо, достигшее 14 лет. По достижении данного возраста гражданин вправе быть участником различных молодежных общественных объединений. Следовательно, с 16 лет лицо, которое непосредственно повлияло на ориентирование молодежной организации на экстремистское направление, подлежит уголовной ответственности. В других общественных организациях данный возраст составляет 18 лет. Для преступников-экстремистов привлекательной является возможность участия в разделе сфер влияния, а также контро- ля над материальными ресурсами. У таких преступников отсутствует первостепенная цель изменить структуру общества и государства либо разжечь ненависть и вражду к определенным социальным группам, установки на изменение структуры общества и государства не имеют в данном случае существенного значения. Приоритетной является возможность контроля над материальными ресурсами и участие в изменении сфер влияния.

\section{Выводы}

Подводя итог вышесказанному, следует отметить, что лиц, совершающих преступления экстремистской направленности, условно можно разделить на несколько категорий: 1) молодые участники группировок и акций массовых протестов; 2) личности с религиозными идеями, являющиеся исполнителями преступлений экстремистской направленности; 3) лица, оказывающие содействие (в том числе организационное и спонсорское) экстремистским сообществам и группам; а также привлекающие преступников-экстремистов для своих властных целей.

Таким образом, приходим к выводу о том, что экстремизм - явление сложное, соответственно, только комплексный подход считается одним из наиболее важных принципов разработки государственной политики в данной области. Необходимо четко осознавать, что причиной подобных проявлений является множество социально-экономических, общеполитических и иных факторов, влияющих как на отдельную личность и ее самосознание, так и на сознание людей в целом [7, с. 233].

\section{СПИСОК ЛИТЕРАТУРЫ}

1. Бурковская, В. А. Криминальный религиозный экстремизм: уголовно-правовые и криминологические основы противодействия : дис. ... д-ра юрид. наук / Бурковская Виктория Алексеевна. - М., 2006. - 350 с.

2. Демидов, Н. Н. Изучение личности преступника в процессе расследования : автореф. дис. ... канд. юрид. наук / Демидов Николай Николаевич. Волгоград, 2003. - 23 с.

3. Долгова, А. И. Теоретические посылки и общая характеристика результатов криминологи- 
ческого изучения личности / А.И. Долгова // Опыт криминологического изучения личности преступника. - М. : Смена, 1981. - С. 22-24.

4. Исакова, Ю. И. Обеспечение правового порядка как механизм предупреждения распространения экстремистской идеологии в социальных сетях / Ю. И. Исакова, С. И. Кузина, Т. Ю. Пастухов // Правовой порядок и правовые ценности : сб. науч. ст. II Всерос. науч.-практ. конф. - Ростов н/Д : ДГТУ-Принт, 2018. - С. 115-120.

5. Кудрявцев, В. Н. Стратегии борьбы с преступностью / В. Н. Кудрявцев. - М. : ЮРАЙТ, 2003.$350 \mathrm{c}$.

6. Сиоридзе, А. Г. Причины возникновения группового молодежного экстремизма / А. Г. Сиоридзе // «Черные дыры» в Российском законодательстве. - 2006. - № 2. - С. 382-386.

7. Яковлева, О. А. Личность преступника в структуре уголовно-правовой и криминологической характеристик деяний, предусмотренных главой 26 УК РФ / О. А. Яковлева // Вестник Волгоградского государственного университета. - 2012. № 2 (17). - C. 230-235.

8. Doha Declaration on the Inclusion of Crime Prevention and Criminal Justice. - Электрон. текстовые дан. - Режим доступа: https://unodc.org/ documents/ congress/Declaration/V1504153. - Загл. с экрана.

\section{REFERENCES}

1. Burkovskaja V.A. Kriminalnyy religioznyy ekstremizm: ugolovno-pravovye i kriminologicheskie osnovy protivodeystviya: dis. ... d-ra yurid. nauk [Criminal Religious Extremism: Criminal Law and Criminological Foundations of Counteraction. Dr. jurid. sci. diss.]. Moscow, 2006.

2. Demidov N.N. Izuchenie lichnosti prestupnika $v$ protsesse rassledovaniya: avtoref. dis. ... kand. yurid. nauk [Investigation of the Identity of the Criminal in the Investigation Process. Cand. jurid. sci. abs. diss.]. Volgograd, 2003.
3. Dolgova A.I. Teoreticheskie posylki i obshchaya kharakteristika rezultatov kriminologicheskogo izucheniya lichnosti [Theoretical Premises and General Characteristics of the Results of a Criminological Study of Personality]. Opyt kriminologicheskogo izucheniya lichnosti prestupnika [The Experience of Criminological Study of the Identity of the Criminal]. Moscow, Smena, 1981, pp. 22-24.

4. Isakova J.I., Kuzina S.I., Pastuhov T.J. Obespechenie pravovogo poryadka kak mekhanizm preduprezhdeniya rasprostraneniya ekstremistskoy ideologii v sotsialnykh setyakh [Ensuring Legal Order as a Mechanism to Prevent the Spread of Extremist Ideology in Social Networks]. Pravovoy poryadok $i$ pravovye tsennosti: sb. nauch. st. II Vseros. nauch.prakt. konf. [Legal Order and Legal Values. Collection of Scientific Articles of the $2^{\text {nd }}$ All-Russian Scientific and Practical Conference]. Rostov-na-Donu, DGTUPrint, 2018, pp. 115-120.

5. Kudrjavcev V.N. Strategii borby $s$ prestupnostyu [Crime Strategies]. Moscow, JuRAJT, 2003. $350 \mathrm{p}$.

6. Sioridze A.G. Prichiny vozniknoveniya gruppovogo molodezhnogo ekstremizma [Reasons for the Emergence of Group Youth Extremism]. «Chernye dyry» $v$ rossiyskom zakonodatelstve ["Black Holes" in Russian Legislation], 2006, no. 2, pp. 382-386.

7. Jakovleva O.A. Lichnost prestupnika $\mathrm{v}$ strukture ugolovno-pravovoy i kriminologicheskoy kharakteristik deyaniy, predusmotrennykh glavoy 26 Ugolovnogo kodeksa Rossiyskoy Federatsii [The Identity of the Offender in the Structure of the Criminal Law and Criminological Characteristics of the Acts Provided for by Chapter 26 of the Criminal Code of the Russian Federation]. Vestnik Volgogradskogo gosudarstvennogo universiteta. Seriya 5, Yurisprudentsiya [Science Journal of Volgograd State University. Jurisprudence], 2012, no. 2(17), pp. 230-235.

8. Doha Declaration on the Inclusion of Crime Prevention and Criminal Justice. URL: https://unodc. org/documents/congress/Declaration/V1504153.

\section{Information About the Author}

Olga A. Yakovleva, Candidate of Sciences (Jurisprudence), Associate Professor, Department of Criminal Law, Volgograd State University, Prosp. Universitetsky, 100, 400062 Volgograd, Russian Federation, olgayakovlev@mail.ru, https://orcid.org/0000-0002-6833-5005

\section{Информация об авторе}

Ольга Алексеевна Яковлева, кандидат юридических наук, доцент кафедры уголовного права, Волгоградский государственный университет, просп. Университетский, 100, 400062 г. Волгоград, Российская Федерация, olgayakovlev@mail.ru, https://orcid.org/0000-0002-6833-5005 